\title{
Association of overweight and obesity with decline in academic performance among female high-school students, Riyadh, Saudi Arabia
}

\author{
M.A. Adaili ', A. G. Mohamed ${ }^{7}$ and H. Alkhashan ${ }^{2}$
}

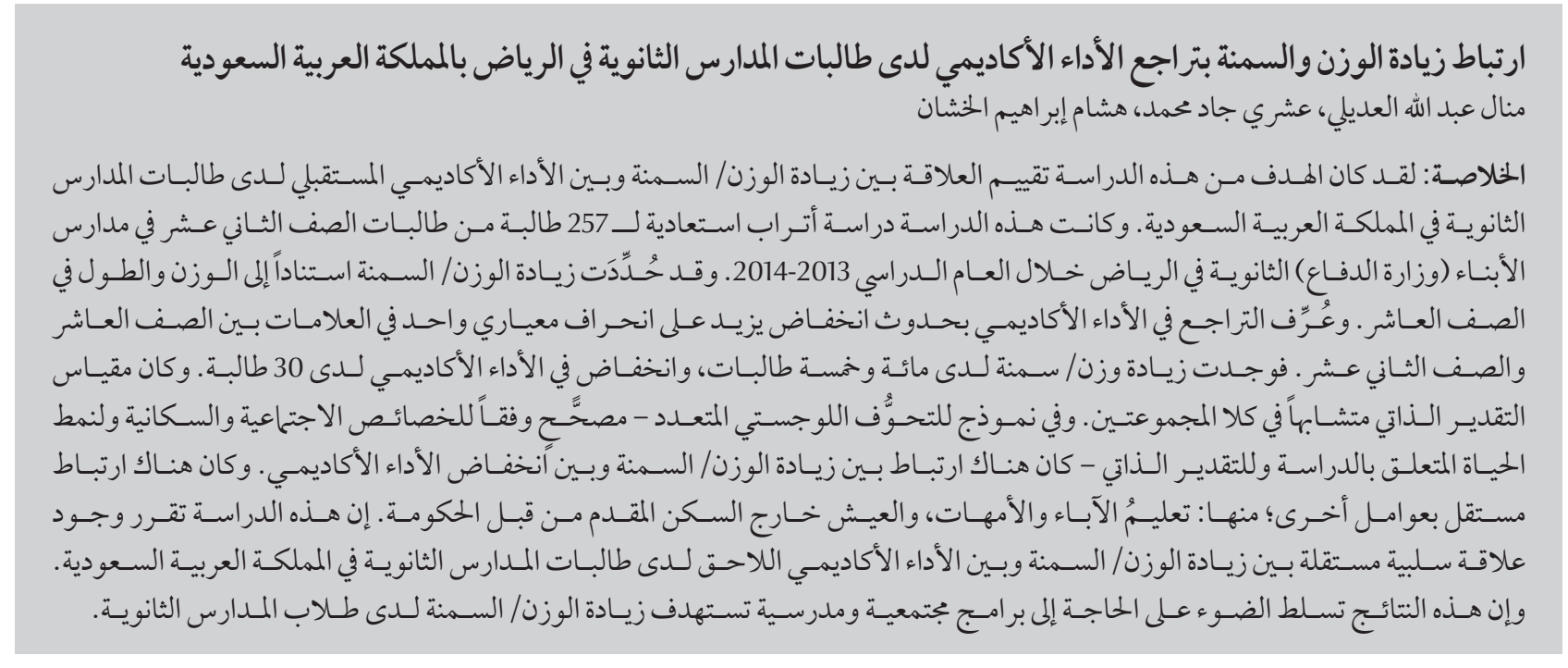

ABSTRACT The aim of this study was to evaluate the association between overweight/obesity and future academic performance among high-school students in Saudi Arabia. This was a retrospective cohort study of 257 12th grade female students in Alabna (Ministry of Defence) high schools in Riyadh during 2013/14. Overweight/obesity was based on weight and height at 10th grade. Decline in academic performance was defined as a reduction by $>1$ standard deviation in marks between 10th and 12th grades. One hundred and five students were overweight/obese and 30 had declined academic performance. Self-esteem scale was similar in both groups. In a multiple logistic regression model adjusted for sociodemographic characteristics, study-related lifestyle and self-esteem, overweight/obesity was associated with declining academic performance. Other independent associates included paternal and maternal education, and living outside governmentally provided housing. We report a negative independent association between overweight/obesity and subsequent academic performance among female high-school students in Saudi Arabia. The results highlight the need for community and school programmes to target overweight/obesity among high-school students.

\section{Association du surpoids et de l'obésité avec la baisse des performances scolaires de lycéennes} à Riyad (Arabie saoudite)

RÉSUMÉ La présente étude avait pour objectif d'évaluerl'association entre le surpoids/l'obésité et les futures performances scolaires de lycéennes en Arabie saoudite. Il s'agissait d'une étude de cohorte rétrospective incluant 257 lycéennes de douzième (classe terminale) au lycée Alabna (Ministère de la Défense) à Riyad entre 2013 et 2014. Le surpoids/l'obésité reposait sur le poids et la taille en classe de dixième (première classe du lycée). La baisse des performances scolaires a été définie comme une réduction de plus d'un écart type dans les notes entre la dixième et la douzième. Cent cinq lycéennes étaient en surpoids ou obèses, et 30 présentaient une baisse des performances scolaires. L'échelle d'estime de soi était similaire dans les deux groupes. Dans un modèle de régression logistique multiple ajusté en fonction des caractéristiques socio-démographiques, du mode de vie et de l'estime dans les études, le surpoids/l'obésité était associé(e) à une baisse des performances scolaires. D'autres éléments associés incluaient l'éducation paternelle et maternelle, et le fait de ne pas disposer d'un logement fourni par l'État. Nous avons rapporté une association indépendante négative entre le surpoids/ l'obésité et les performances scolaires ultérieures des lycéennes en Arabie saoudite. Les résultats soulignent le besoin de programmes communautaires et scolaires pour cibler le surpoids/I'obésité parmi les lycéennes.

${ }^{\prime}$ Family and Community Medicine Department, College of Medicine, King Saud University, Riyadh, Saudi Arabia (Correspondence to: M.A. Adaili: dr.adaili@gmail.com); ${ }^{2}$ Family and Community Medicine Department, Prince Sultan Military Medical City, Riyadh, Saudi Arabia.

Received: 09/09/15; accepted: 31/08/16 


\section{Introduction}

Over the last few decades, there has been a worldwide increase in childhood obesity affecting developed and developing countries (1). In the United States of America, the prevalence of obesity among adolescents aged 12-19 years increased from 5\% in 1980 to nearly $21 \%$ in 2012 (2,3). In Saudi Arabia, several local and national reports have shown a similar problem, with the prevalence of overweight and obesity among adolescent children ranging between $30 \%$ and $46 \%$ (4-6). As childhood obesity is likely to continue into adulthood, it puts the affected children at higher risk of obesity-related disorders such as diabetes and cardiovascular, respiratory, gastrointestinal and orthopaedic diseases at a younger age (7). Additionally, childhood obesity and associated distorted perception of body image can have a serious negative impact on child psychology, self-esteem and quality of life $(8-10)$.

Several studies have examined the association between overweight/ obesity and academic performance among students at different grades of elementary education, with conflicting findings. For example, several studies reported reduced academic performance in obese children (11-14), while other studies among primary school students failed to detect such an association (15-17). Additionally, gender-specific variability in the relationship between overweight/obesity and academic performance has been reported. Obese girls had lower academic achievement compared with those of a healthy weight. However, such an association was less clear in boys (12). In Chinese adolescents, overweight perception was related to lower GPA in girls only (8).

There is a poor understanding of the underlying mechanisms $(14,18,19)$.

Despite the high prevalence of childhood/adolescent obesity and the importance of academic performance of high-school students in shaping their future education $(20,21)$, there has been a lack of studies of the association between overweight/obesity and academic performance among Saudi Arabian students. The objective of the current study was to evaluate the association between overweight/obesity and future overall academic performance among high-school students in Saudi Arabia.

\section{Methods}

\section{Setting}

The current study was conducted at the Alabna (Ministry of Defence) high schools, which include 5 female schools, located in Riyadh, Saudi Arabia. As these schools are exclusively serving children of employees in the Ministry of Defence, the schools are jointly managed by the Ministry of Education and Ministry of Defence. The female schools served 1289 high-school students in 2014, with 384 students in the 12th grade.

\section{Study design}

This was a retrospective cohort study. We obtained all required ethical approvals from the Institutional Review Board (IRB) of King Saud University and IRB of Prince Sultan Military Medical City.

\section{Study population}

The study was carried among 12th grade students during the 2013/14 academic year. Potential candidates for the study were all students who had mid-year marks for the 12th grade (2013/14), final year marks for the 10th grade (2011/12), and 10th grade height and weight measurements. We excluded students whose guardians refused to give consent, those with chronic diseases, and those who did not complete the study questionnaire.

\section{Sample size}

As shown in previous studies in Saudi Arabia (4-6), we assumed that the ratio of normal weight to overweight/ obesity among the students would be 2: 1 . As per the study definition, the decline in academic performance ( $>1$ standard deviation; SD) was expected at a prevalence of $\sim 16 \%$, assuming a normal distribution. It was estimated that at least 260 students were required to detect a $15 \%$ difference in academic decline between the two study groups ( $10 \%$ vs $25 \%$ ), at $95 \%$ confidence level and $90 \%$ power.

\section{Exposure definition}

Overweight/obesity was based on body mass index (BMI) calculated from weight $(\mathrm{kg})$ and height $(\mathrm{cm})$ measurements obtained from students' school health medical records or records in Riyadh Military Hospital databases during the 10th grade (2011/12). The cutoff point for overweight/obesity was the $85 \%$ percentile based on the 2000 Centers for Disease Control and Prevention BMI-for-age percentiles charts. This was equivalent to 24.6 for female students aged 16 years.

\section{Outcome definition}

Decline in academic performance was defined as a $>1$ SD reduction between mid-year marks at 12 th grade (2013/14) and final year marks at 10th grade $(2011 / 12)$, to allow better comparisons of relative changes across tests (22). The students' marks were obtained from official school records after obtaining permission from the Ministry of Education and students' guardians. The marks of the 10th and 12th grades were chosen to outline the beginning and end of the high-school years. Midyear rather than final marks of the 12th grade were chosen to improve the response rate, as recruiting students outside the school during the summer vacation would have been difficult. 


\section{Questionnaire}

We developed and administered a self-administrated questionnaire to all students. The students were asked to answer questions about socioeconomic factors and study-related lifestyle habits such as watching television (number of hours), internet and computer use (yes/no), study room availability and adequacy (yes/no), and current smoking (yes/no). Self-esteem was assessed using the 10-item Rosenberg SelfEsteem Scale, which was answered using a 4-point Likert scale ranging from strongly agree to strongly disagree (23). The scale items were translated into Arabic and back translated to English to detect any variability.

\section{Recruitment}

Students whose guardians agreed to study participation were asked to complete the study questionnaire. This was done during field visits to each school and the questionnaires were completed under supervision of the researcher, to respond to any inquiry and improve the quality of data. The response rate was $83.1 \%(310 / 373)$.

\section{Statistical analysis}

Data are presented using frequencies and percentages for categorical data and mean (SD) for continuous data. Significant differences in sociodemographic characteristics, study-related lifestyle habits and self-esteem among overweight/obese and other students were evaluated using the $\mathcal{X}^{2}$ or Fisher's exact test for categorical data and Student's $t$ test or Mann-Whitney $U$ test for continuous data. Decline in academic performance was compared between the two study groups. To detect independent associations between student characteristics (including overweight/obesity status) and the decline in academic performance, multiple logistic regression models were run, using backward elimination. The confidentiality of data was assured through anonymous analysis of coded questionnaires and allowing access to data only for researchers and for the purposes stated in the signed consent. All $P$ values were 2 -tailed. $P<0.05$ was considered to be significant. SPSS version 20.0 (SPSS Inc., Chicago, IL, USA) was used for all statistical analyses.

\section{Results}

Out of 373 female students of Alabna high schools who had 12th grade marks available, 33 (8.8\%) were missing the 10th grade marks. Out of the 340 highschool students who had 10th and 12th grade marks available, 25 (7.4\%) did not have 10th grade BMI measurements and $63(18.5 \%)$ did not complete the study questionnaire. This left $257 \mathrm{stu}-$ dents for the current analysis. The average BMI was $23.2 \pm 5.7$. Female growth charts showed that $105(40.9 \%)$ out of the 257 students were either overweight $(53,20.6 \%)$ or obese $(52,20.2 \%)$.

Table 1 shows the sociodemographic characteristics of the students. The majority (251, 97.7\%) were living with both parents with an average family size of $6.1 \pm 2.4$ individuals. Most (170, $67.5 \%$ ) fathers were aged $\geq 45$ years, whereas most $(201,78.5 \%)$ mothers were aged $<45$ years. One hundred and four (41.3\%) fathers and 69 (27.3\%) mothers had college or graduate education, whereas $53(21.0 \%)$ fathers and 127 (50.2\%) mothers had less than secondary education. One hundred and ninety $(75.7 \%)$ fathers were working in military occupations, with 78 (30.5\%) as officers and 115 (44.9\%) not as officers. Only 53 (20.7\%) mothers were working and the rest were housewives. One hundred and forty-one (55.7\%) students were living in governmentally provided housing facilities.

As shown in Table 2, 154 (60.2\%) students had a designated non-noisy place for studying. Two hundred and thirty $(89.8 \%)$ had their own computer and $244(96.1 \%)$ had internet access. On average, the students were watching television for $2.3 \pm 1.6$ hours per day. Only one (0.4\%) student reported smoking. Out of a maximum 30 points, the average self-esteem scale was $20.6 \pm$ 4.0 points. The average marks (per 100) were $86.5 \pm 9.7$ for 10th grade and 89.5 \pm 9.2 for 12 th grade, with an average improvement of $3.1 \pm 6.6$ marks. Using standardized difference (12th minus $10^{\text {th }}$ grade marks), 30 students (11.7\%) had declined academic performance (< 1 SD) and 227 (88.3\%) had constant or improved academic performance ( $>1$ SD) (Figure 1).

Comparing student characteristics by overweight/obesity status (Tables 1 and 2), only having an older (> 55 years) father $(P=0.009)$, prolonged television watching $(P=0.038)$, and to a lesser extent, living in non-governmentally provided housing $(P=0.053)$ were associated with being overweight or obese in the $10^{\text {th }}$ grade. Self-esteem scale points were similar in both groups $(20.5 \pm 4.0$ vs $20.8 \pm 4.0, P=0.921)$. The decline in academic performance according to overweight/obesity status is shown in Figure 1. Overweight/obese students had a significantly greater decline in academic performance as compared with their nonoverweight peers $(18.1 \%$ vs $7.2 \%, P=0.023)$.

The results of multiple logistic regression models that were adjusted for all the above student characteristics (sociodemographic characteristics, study-related lifestyle habits, and selfesteem) are shown in Table 3. Being overweight/obese was associated with a higher decline in academic performance (odds ratio $=3.73,95 \%$ confidence interval $=1.30-10.74, P=0.015$ ) even after adjusting for the above characteristics. Additionally, having a father with low (secondary) education $(P=$ $0.014)$ and living outside the governmentally provided housing $(P=0.008$ for owned and $P=0.003$ for rented housing) were independently associated with greater decline in academic performance. In contrast, having a mother with less than secondary education was 


\begin{tabular}{|c|c|c|c|c|}
\hline & $\begin{array}{c}\text { Not overweight } \\
\qquad n=152\end{array}$ & $\begin{array}{c}\text { Overweight/obese } \\
\qquad n=105\end{array}$ & $\begin{array}{c}\text { Total } \\
n=257\end{array}$ & $P$ value* \\
\hline Age & $18.0 \pm 0.0$ & $18.0 \pm 0.0$ & $18.0 \pm 0.0$ & - \\
\hline Height $(\mathrm{cm})$ & $156.2 \pm 4.6$ & $156.8 \pm 5.4$ & $156.5 \pm 5.0$ & 0.327 \\
\hline Weight (kg) & $47.9 \pm 6.1$ & $70.2 \pm 14.2$ & $57.0 \pm 15.0$ & $<0.001$ \\
\hline Body mass index (BMI) & $19.6 \pm 2.2$ & $28.4 \pm 4.6$ & $23.2 \pm 5.5$ & $<0.001$ \\
\hline \multicolumn{5}{|l|}{ Student living with: } \\
\hline Father & $1(0.7 \%)$ & $1(1.0 \%)$ & $2(0.8 \%)$ & 1.000 \\
\hline Mother & $2(1.3 \%)$ & $2(1.9 \%)$ & $4(1.6 \%)$ & 1.000 \\
\hline Both & $149(98.0 \%)$ & $102(97.1 \%)$ & $251(97.7 \%)$ & 1.000 \\
\hline Family size & $6.0 \pm 2.2$ & $6.3 \pm 2.6$ & $6.1 \pm 2.4$ & 0.284 \\
\hline \multicolumn{5}{|l|}{ Father age (yr) } \\
\hline$<45$ & $50(33.8 \%)$ & $32(30.8 \%)$ & $82(32.5 \%)$ & 0.009 \\
\hline $45-55$ & $90(60.8 \%)$ & $54(51.9 \%)$ & $144(57.1 \%)$ & 0.009 \\
\hline$>55$ & $8(5.4 \%)$ & $18(17.3 \%)$ & $26(10.3 \%)$ & 0.009 \\
\hline \multicolumn{5}{|l|}{ Mother age (yr) } \\
\hline$<45$ & $124(81.6 \%)$ & $77(74.0 \%)$ & $201(78.5 \%)$ & 0.149 \\
\hline$\geq 45$ & $28(18.4 \%)$ & $27(26.0 \%)$ & $55(21.5 \%)$ & 0.149 \\
\hline \multicolumn{5}{|l|}{ Father's education } \\
\hline Below secondary education & $28(18.9 \%)$ & $25(24.0 \%)$ & $53(21.0 \%)$ & 0.159 \\
\hline Secondary education & $63(42.6 \%)$ & $32(30.8 \%)$ & $95(37.7 \%)$ & 0.159 \\
\hline College or graduate & $57(38.5 \%)$ & $47(45.2 \%)$ & $104(41.3 \%)$ & 0.159 \\
\hline \multicolumn{5}{|l|}{ Mother's education } \\
\hline Below secondary education & $75(50.0 \%)$ & $52(50.5 \%)$ & $127(50.2 \%)$ & 0.332 \\
\hline Secondary education & $38(25.3 \%)$ & $19(18.4 \%)$ & $57(22.5 \%)$ & 0.332 \\
\hline College or graduate & $37(24.7 \%)$ & $32(31.1 \%)$ & $69(27.3 \%)$ & 0.332 \\
\hline \multicolumn{5}{|l|}{ Father in military } \\
\hline No & $33(22.1 \%)$ & $28(27.5 \%)$ & $61(24.3 \%)$ & 0.336 \\
\hline Yes & $116(77.9 \%)$ & $74(72.5 \%)$ & $190(75.7 \%)$ & 0.336 \\
\hline \multicolumn{5}{|l|}{ Father's job status } \\
\hline Officer & $44(28.9 \%)$ & $34(32.7 \%)$ & $78(30.5 \%)$ & 0.328 \\
\hline Not officer & $74(48.7 \%)$ & $41(39.4 \%)$ & $115(44.9 \%)$ & 0.328 \\
\hline Other & $34(22.4 \%)$ & $29(27.9 \%)$ & $63(24.6 \%)$ & 0.328 \\
\hline \multicolumn{5}{|l|}{ Mother's job status } \\
\hline Working & $30(19.7 \%)$ & $23(22.1 \%)$ & $53(20.7 \%)$ & 0.645 \\
\hline Housewife & $122(80.3 \%)$ & $81(77.9 \%)$ & $203(79.3 \%)$ & 0.645 \\
\hline \multicolumn{5}{|l|}{ Home type } \\
\hline Owned & $43(28.7 \%)$ & $35(34.0 \%)$ & $78(30.8 \%)$ & 0.053 \\
\hline Rented & $15(10.0 \%)$ & $19(18.4 \%)$ & $34(13.4 \%)$ & 0.053 \\
\hline Government provided & $92(61.3 \%)$ & $49(47.6 \%)$ & $141(55.7 \%)$ & 0.053 \\
\hline
\end{tabular}

* $x^{2}$ test or Fisher's exact test for categorical data and t test for continuous data

independently associated with lesser decline in academic performance $(P=$ 0.039).

\section{Discussion}

We reported a negative association between overweight/obesity and subsequent (2-year) academic performance measured among a sample of female high-school students in Saudi Arabia. This is in accordance with the majority of previous studies. For example, in a recent longitudinal study in the United Kingdom of Great Britain and Northern Ireland, obese students at age 11 years had reduced subsequent academic performance measured 5 years later compared with those of a healthy weight (12). Similarly, the negative association between overweight/obesity and concurrent academic performance was seen in several cross-sectional studies $(13,14,24)$, 


\begin{tabular}{|c|c|c|c|c|}
\hline & $\begin{array}{c}\text { Not overweight } \\
\qquad n=152\end{array}$ & $\begin{array}{l}\text { Overweight/obese } \\
\qquad n=105\end{array}$ & $\begin{array}{c}\text { Total } \\
n=257\end{array}$ & $P$ value* \\
\hline \multicolumn{5}{|l|}{ Designated study place } \\
\hline No & $59(39.3 \%)$ & $36(34.3 \%)$ & $95(37.3 \%)$ & 0.412 \\
\hline Yes & $91(60.7 \%)$ & $69(65.7 \%)$ & $160(62.7 \%)$ & 0.412 \\
\hline \multicolumn{5}{|l|}{ Noisy study place } \\
\hline No & 88 (57.9\%) & $66(63.5 \%)$ & $154(60.2 \%)$ & 0.372 \\
\hline Yes & $64(42.1 \%)$ & $38(36.5 \%)$ & $102(39.8 \%)$ & 0.372 \\
\hline \multicolumn{5}{|l|}{ Having internet access } \\
\hline No & $6(4.0 \%)$ & $4(3.8 \%)$ & $10(3.9 \%)$ & 1.000 \\
\hline Yes & $144(96.0 \%)$ & $100(96.2 \%)$ & $244(96.1 \%)$ & 1.000 \\
\hline \multicolumn{5}{|l|}{ Smoking } \\
\hline No & $150(99.3 \%)$ & $105(100.0 \%)$ & $255(99.6 \%)$ & 1.000 \\
\hline Yes & $1(0.7 \%)$ & $0(0.0 \%)$ & $1(0.4 \%)$ & 1.000 \\
\hline Television watching (h) & $2.1 \pm 1.5$ & $2.5 \pm 1.7$ & $2.3 \pm 1.6$ & 0.038 \\
\hline Self-esteem scale points & $20.5 \pm 4.0$ & $20.8 \pm 4.0$ & $20.6 \pm 4.0$ & 0.0921 \\
\hline \multicolumn{5}{|l|}{ Self-esteem scale groups } \\
\hline Low tertile & $46(30.3 \%)$ & $31(29.5 \%)$ & $77(30.0 \%)$ & 0.883 \\
\hline Middle tertile & $54(35.5 \%)$ & $35(33.3 \%)$ & $89(34.6 \%)$ & 0.883 \\
\hline High tertile & $52(34.2 \%)$ & $39(37.1 \%)$ & $91(35.4 \%)$ & 0.883 \\
\hline 10th grade mark (percentage) & $87.3 \pm 9.6$ & $85.3 \pm 9.8$ & $86.5 \pm 9.7$ & 0.094 \\
\hline \multicolumn{5}{|l|}{ 10th grade mark (percentile) } \\
\hline Lowest 10th & $13(8.6 \%)$ & $11(10.5 \%)$ & $24(9.3 \%)$ & 0.872 \\
\hline 10th-90th & $121(79.6 \%)$ & $82(78.1 \%)$ & $203(79.0 \%)$ & 0.872 \\
\hline Highest 10th & $18(11.8 \%)$ & $12(11.4 \%)$ & $30(11.7 \%)$ & 0.872 \\
\hline 12th grade mark (percentage) & $91.0 \pm 8.1$ & $87.5 \pm 10.4$ & $89.5 \pm 9.2$ & 0.004 \\
\hline \multicolumn{5}{|l|}{ 12th grade mark (percentile) } \\
\hline Lowest 10th & $7(4.6 \%)$ & $15(14.3 \%)$ & $22(8.6 \%)$ & 0.019 \\
\hline 10th-90th & $130(85.5 \%)$ & $78(74.3 \%)$ & $208(80.9 \%)$ & 0.019 \\
\hline Highest 10th & $15(9.9 \%)$ & $12(11.4 \%)$ & $27(10.5 \%)$ & 0.019 \\
\hline Mark difference (percentage) & $3.7 \pm 5.6$ & $2.2 \pm 7.7$ & $3.1 \pm 6.6$ & 0.107 \\
\hline Mark difference (SD) & $0.09 \pm 0.85$ & $-0.13 \pm 1.18$ & $0.00 \pm 1.00$ & 0.107 \\
\hline
\end{tabular}

${ }^{*} \chi^{2}$ test or Fisher's exact test for categorical data and Mann-Whitney $U$ test for continuous data

including some with female students only $(8,12)$. For example, perceived overweight among Chinese adolescents was associated with low self-reported grade point average (GPA) in female but not male students (8). In contrast, several studies conducted among primary-school students in different parts of the world failed to detect an association between overweight/obesity and concurrent academic performance (15-17). This failure was attributed to level of adjustment for confounding variables, especially socioeconomic and psychosocial factors, differences in the analytical techniques used, and differences in the age or ethnicity of the study samples $(15,16)$.

Several explanations have been suggested for the negative association between BMI and academic performance. These include higher rates of healthrelated school absenteeism (25), reduced cognitive function (26), negative impact on self-esteem (9), concurrent depressive symptoms (8), and finally, peer and teacher prejudice $(14,18)$. However, such a negative association was shown in previous studies to be independent of depressive symptoms, intelligence quotient (IQ) and several sociodemographic characteristics (12, 13). Additionally, the negative association between overweight/obesity and academic performance in the current study was independent of level of selfesteem and several potential sociodemographic and lifestyle confounders. The independent effect of paternal and maternal education and type housing on academic performance in the current study indicates that decline in 


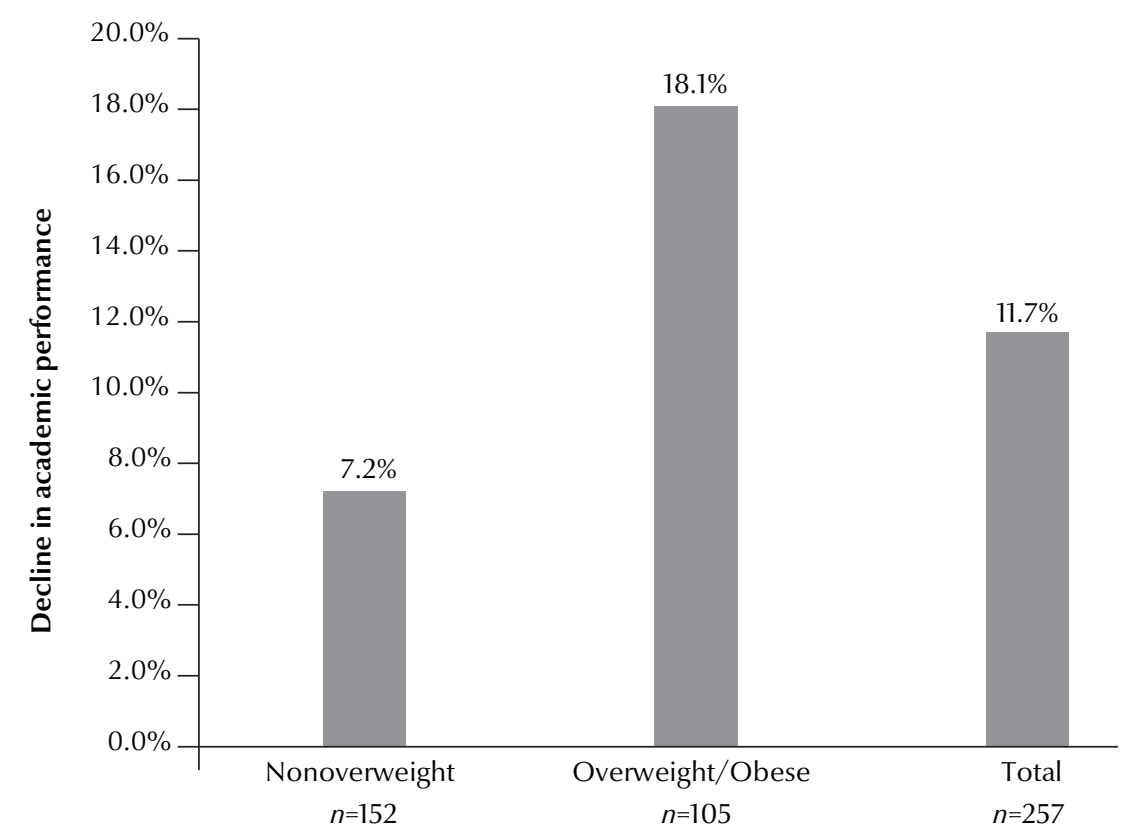

Figure 1 Academic decline (by $>1$ standard deviation) among students according to overweight/obesity status.

academic performance is a multifactorial problem, with overweight/obesity playing a major role.

The significant negative impact of overweight/obesity on future academic performance may need to be confirmed in both genders and in schools in different parts of Saudi Arabia before the findings can be confidently generalized to
Additionally, the current findings may provide parents and adolescents with greater motivation to engage with initiatives to prevent childhood obesity (12).

The current study had many advantages, such as filling the local knowledge gap in an adolescent population with high prevalence of overweight/obesity. The prospective design helped to suggest the causality between overweight/ obesity and subsequent academic performance. The use of documented BMI and academic marks removed the impact of recall and self-perception biases. Nevertheless, we acknowledge several limitations. The study included only female students of military personnel in one city, therefore, the results should be generalized with caution to Saudi Arabian high-school students. Lack of data on some related factors such as absenteeism, IQ psychological problems and physical activity may have limited our ability to adjust fully for possible confounding. Although we planned to include both genders, only data of female students were included in the current analysis to avoid selection bias caused by the low response rate among male students.

In conclusion, we report a negative independent association between BMI

\begin{tabular}{|c|c|c|c|c|}
\hline & OR & Lower $\mathrm{Cl}$ & Upper Cl & $P$ value \\
\hline Overweight/obesity (ref: normal weight) & 3.73 & 1.3 & 10.74 & 0.015 \\
\hline \multicolumn{5}{|l|}{ Father's education (ref: college/graduate) } \\
\hline Below secondary education & 2.68 & 0.45 & 15.9 & 0.277 \\
\hline Secondary education & 5.14 & 1.4 & 18.89 & 0.014 \\
\hline \multicolumn{5}{|l|}{ Mother's education } \\
\hline Below secondary education & 0.17 & 0.03 & 0.91 & 0.039 \\
\hline Secondary education & 0.91 & 0.19 & 4.48 & 0.909 \\
\hline Working mothers (ref: housewives) & 0.2 & 0.04 & 1.08 & 0.061 \\
\hline \multicolumn{5}{|l|}{ Home type (ref: government provided) } \\
\hline Owned & 5.84 & 1.58 & 21.53 & 0.008 \\
\hline Rented & 8.58 & 2.06 & 35.72 & 0.003 \\
\hline
\end{tabular}

$C I=$ confidence interval; $O R=$ odds ratio.

Variables entered and left the model; student living status, father's age, mother's age, father working in military, father's work type, family size, designated study place, noisy study place, having own computer, having internet access, $7 \mathrm{~V}$ watching hours, smoking, and self-esteem scale points. 
and subsequent academic performance among female high-school students in Saudi Arabia. The current findings highlight the need for community and school programmes targeting overweight/obesity among high-school students.

\section{Acknowledgements}

The authors would like to thank the Ministry of Education for its cooperation in obtaining some of the data required for this research. Also, the
School Health Team members in Prince Sultan Military Medical City are acknowledged for their assistance in the data collection.

Funding: None.

Conflict of interest: None declared.

\section{References}

1. Lobstein T, Baur L, Uauy R; IASO International Obesity TaskForce. Obesity in children and young people: a crisis in public health. Obes Rev. 2004 May;5 Suppl 1:4-104.

2. Ogden CL, Carroll MD, Kit BK, Flegal KM. Prevalence of childhood and adult obesity in the United States, 2011-2012. JAMA. 2014 Feb 26;311(8):806-14.

3. Health, United States, 2011: with special features on socioeconomic status and health. Hyattsville, MD: National Center for Health Statistics; 2012 (http://www.cdc.gov/nchs/data/hus/ hus11.pdf; accessed 10 October 2016).

4. Al Shehri A, Al Alwan I, Al Fattani A. Obesity among Saudi children. Saudi J Obes. 2013;1(1):3-9 (http://www.saudijobesity. com/article.asp?issn=2347-2618; year=2013; volume=1; issue=1; spage $=3$; epage $=9$; aulast $=\mathrm{Al}$ ).

5. Al-Dossary SS, Sarkis PE, Hassan A, Ezz El Regal M, Fouda AE. Obesity in Saudi children: a dangerous reality. East Mediterr Health J. 2010 Sep;16(9):1003-8.

6. El Mouzan MI, Al Herbish AS, Al Salloum AA, Al Omar AA, Qurachi MM. Regional variation in prevalence of overweight and obesity in Saudi children and adolescents. Saudi J Gastroenterol. 2012 Mar-Apr;18(2):129-32.

7. Daniels SR. Complications of obesity in children and adolescents. Int J Obes (Lond). 2009 Apr;33 Suppl 1:S60-5.

8. Xie B, Chou CP, Spruijt-Metz D, Reynolds K, Clark F, Palmer $\mathrm{PH}$, et al. Weight perception, academic performance, and psychological factors in Chinese adolescents. Am J Health Behav. 2006 Mar-Apr;30(2):115-24.

9. Ortega Becerra MA, Muros JJ, Palomares Cuadros J, Martin Sanchez JA, Cepero Gonzalez M. [Influence of body mass index on self-esteem of children aged 12-14 years]. An Pediatr (Barc). 2015 Nov;83(5):311-7 (in Spanish).

10. Swallen KC, Reither EN, Haas SA, Meier AM. Overweight, obesity, and health-related quality of life among adolescents: the National Longitudinal Study of Adolescent Health. Pediatrics. 2005 Feb;115(2):340-7.

11. Taras H, Potts-Datema W. Obesity and student performance at school. J Sch Health. 2005 Oct;75(8):291-5.

12. Booth JN, Tomporowski PD, Boyle JM, Ness AR, Joinson C, Leary SD, et al. Obesity impairs academic attainment in adolescence: findings from ALSPAC, a UK cohort. Int J Obes (Lond). 2014 Oct;38(10):1335-42.

13. Kim JH, So WY. Association between overweight/obesity and academic performance in South Korean adolescents. Cent Eur J Public Health. 2013 Dec;21(4):179-83.

14. Krukowski RA, WestDS, Philyaw PerezA, BursacZ, Phillips MM, Raczynski JM. Overweight children, weight-based teasing and academic performance. Int J Pediatr Obes. 2009;4(4):274-80.
15. Chen LJ, Fox KR, Ku PW, Wang CH. A longitudinal study of childhood obesity, weight status change, and subsequent academic performance in Taiwanese children. J Sch Health. 2012 Sep;82(9):424-31.

16. Barrigas C, Fragoso I. Obesity, academic performance and reasoning ability in Portuguese students between 6 and 12 years old. J Biosoc Sci. 2012 Mar;44(2):165-79.

17. Baxter $\mathrm{SD}$, Guinn $\mathrm{CH}$, Tebbs JM, Royer JA. There is no relationship between academic achievement and body mass index among fourth-grade, predominantly African-American children. J Acad Nutr Diet. 2013 Apr;113(4):551-7.

18. MacCann C, Roberts RD. Just as smart but not as successful: obese students obtain lower school grades but equivalent test scores to nonobese students. Int J Obes (Lond). 2013 Jan;37(1):40-6.

19. Kesztyüs D, Wirt T, Kobel S, Schreiber A, Kettner S, Dreyhaupt $\mathrm{J}$, et al.; "Komm mit in das gesunde Boot-Grundschule" - Research Group. Is central obesity associated with poorer health and health-related quality of life in primary school children? Cross-sectional results from the Baden-Württemberg Study. BMC Public Health. 201303 22;13:260.

20. Al-Alwan IA. Association between scores in high school, aptitude and achievement exams and early performance in health science college. Saudi J Kidney Dis Transpl. May 2009;20(3):448-53.

21. Murshid KR. The predictive value of individual admission criteria on academic performance in a Saudi medical college. J Taibah Univ Med Sci. 2013 Apr;8(1):18-23 (http://www.sciencedirect.com/science/article/pii/S1658361213000061).

22. Van Dusen DP, Kelder SH, Kohl HW 3rd, Ranjit N, Perry CL. Associations of physical fitness and academic performance among schoolchildren. J Sch Health. 2011 Dec;81(12):733-40.

23. Rosenberg M. Society and the adolescent self-image. Princeton: Princeton University Press; 1965.

24. Florin TA, Shults J, Stettler N. Perception of overweight is associated with poor academic performance in US adolescents. J Sch Health. 2011 Nov;81(11):663-70.

25. Pan L, Sherry B, Park S, Blanck HM. The association of obesity and school absenteeism attributed to illness or injury among adolescents in the United States, 2009. J Adolesc Health. 2013 Jan;52(1):64-9.

26. Li Y, Dai Q, Jackson JC, Zhang J. Overweight is associated with decreased cognitive functioning among schoolage children and adolescents. Obesity (Silver Spring). 2008 Aug;16(8):1809-15.

27. Al-Hazzaa HM. Obesity and physical inactivity among saudi children and youth: challenges to future public health. J Family Community Med. 2006 May;13(2):53-4. 